\title{
Religião e política no Peru pós-Fujimori
}

\author{
Paulo Barrera Rivera*
}

Nas últimas décadas, os evangélicos na América Latina mudaram sua forma de compreender o lugar da religião na sociedade e na política. Constata-se essa mudança em diversos campos da prática social, entre eles o da participação política eleitoral. Em contraste com o passado recente, tornou-se fato comum o surgimento de organizações políticas evangélicas cujo principal objetivo é obter quotas ou espaços de poder ou de influência política, concorrendo em pé de igualdade com outras organizações políticas. A diferença encontra-se no fato de que os evangélicos agem, ou dizem agir, no terreno da política a partir de princípios religiosos. Hoje existem partidos e associações políticos evangélicos na maioria dos países de América Latina, em geral com projetos restritos à disputa eleitoral. Este trabalho explora a informação disponível sobre o comportamento político dos evangélicos nas eleições das últimas décadas no Peru. Toma como referência as eleições de 1990, quando Alberto Fujimori foi eleito, tendo em conta que nessas eleições os evangélicos inauguraram um novo comportamento político eleitoral distinto de sua prática política tradicional.

* Docente do Programa de Pós-Graduação em Ciências da Religião, da Universidade Metodista de São Paulo.

\begin{tabular}{|c|c|c|c|c|c|}
\hline Civitas & Porto Alegre & v. 6 & n. 2 & jul.-dez. 2006 & p. 55-75 \\
\hline
\end{tabular}




\section{Evangélicos e política no Peru}

$\mathrm{Na}$ avaliação da participação política dos evangélicos são de singular importância os dados quantitativos: porcentagem da população que se declara evangélica, número de votos e candidatos. Para o caso do Peru, a informação censitária disponível é apenas do ano 1993. O último censo, realizado em julho de 2005, infelizmente não incluiu pergunta sobre religião. Até os primeiros meses deste ano e durante a elaboração do questionário do Censo, sabia-se que estava prevista a questão religiosa, mas ela foi retirada sem que se soubesse a razão. Suspeita-se que a Igreja Católica tenha influenciado na decisão de retirar ou ocultar a questão sobre religião, visando ocultar a queda do número de seus seguidores. Peru é o país da América Latina com mais bispos da Opus Dei, que têm muita influência nas instâncias oficiais do Governo. Voltando aos dados do Censo de 1993, os católicos constituíam pouco mais de $90 \%$ da população, e os evangélicos pouco menos de $7 \%$. Há razões para supor elevado crescimento dos evangélicos nos últimos 15 anos, a julgar pela multiplicação de templos. Segundo o Promies (Projección Misionera y Estudios Socioreligiosos), departamento do Concilio Nacional Evangélico del Perú, entidade que reúne as igrejas evangélicas mais representativas, os evangélicos somavam um milhão de pessoas e constituíam $5 \%$ da população em 1990, ano da eleição de Fujimori.

Avaliamos a seguir o volume de votos angariados pelos evangélicos nas eleições gerais de 1990, 1995, 2000, 2003 e 2006. A partir das características religiosas dos candidatos determinamos as mudanças na prática política e dos atores políticos evangélicos. Com isso, pretendemos mostrar as mudanças na mentalidade evangélica a respeito da política. Iniciamos a abordagem da questão remontando à prática política de evangélicos pioneiros na participação política eleitoral no país. Atentamos para o agir político desses indivíduos porque corresponde ao período de constituição da tradicional mentalidade evangélica sobre a política. Limitamos a destacar dados e fatos históricos indispensáveis para melhor compreender a questão central deste trabalho, a saber, a participação política dos evangélicos nos processos eleitorais a partir de 1990. 


\section{Evangélicos e política}

Tradicionalmente foi característico dos evangélicos no Peru, como em outros países da América Latina, considerar o espaço político alheio ao compromisso religioso. A ética protestante, herdada de diferentes grupos missionários vindos da Europa e dos Estados Unidos, propunha o modelo do bom cidadão, cumpridor dos deveres cívicos. A mentalidade dos evangélicos distinguia claramente o espaço do religioso do espaço do social e da política. A responsabilidade política limitava-se ao sufrágio. Salvo exceções, qualquer outra prática política era vista com desconfiança. Os primeiros evangélicos que incursionaram com sucesso na disputa política como candidatos o fizeram como indivíduos e sem qualquer apoio oficial ou participação de suas igrejas. O primeiro deles, o advogado José Ferreira, foi deputado em 1956 e senador em 1963, 1968 e 1985. Ferreira era membro leigo da Iglesia Evangélica Peruana, fundada no final do 19 por missionários da Igreja Presbiteriana Livre de Escócia. Em todas essas décadas Ferreira foi um tipo de "candidato dos evangélicos", sendo o único evangélico a participar como candidato. Mesmo sem formação teológica, Ferreira gozava de prestígio entre os evangélicos, especialmente porque sua igreja permitia o exercício de leigos em postos de direção e do pastorado. A Iglesia Evangélica Peruana administra suas congregações através do consistório, que é formado por um conjunto de “anciãos". Sendo a membresia da Iglesia Evangélica Peruana composta majoritariamente por pessoas pobres, não era difícil que um advogado e ao mesmo tempo "ancião" e autoridade política, obtivesse elevado reconhecimento dos evangélicos; não apenas dos membros dessa denominação, mas também das outras igrejas evangélicas.

Durante a maior parte de sua carreira política, Ferreira foi militante da Acción Popular Revolucionaria Americana (Apra), partido de origem de centro-esquerda que, distintamente de todas as frações da esquerda marxista, considerava a religião fator importante na construção da nação e na transformação da sociedade. ${ }^{1}$ Ferreira era conhecido como "Don José”, expressão

\footnotetext{
Desde suas origens, na década de 1930, o Apra disputaria com o Partido Comunista Peruano o apoio das massas trabalhadoras urbanas. Mas, no decorrer da sua história, estratégias eleitorais levaram o Apra a costurar alianças com partidos e propostas de direita. Essa ambigüidade ideológica tornou-se mais evidente no período que aqui analisamos e se reflete na forma como nos referimos a esse partido ao longo do texto.
} 
que o distinguia dos demais "irmãos". Não consta que tenha obtido o título de doutor, embora fosse chamado de "Dr. Ferreira". Sem dúvida, o carisma de Ferreira e seu prestígio contribuíram para a enorme simpatia que o Partido Aprista desfrutou, até a década de 80 , nos meios evangélicos, que deviam votar nos candidatos do Apra.

Ainda hoje, os líderes evangélicos mais antigos se referem ao Apra como “o partido", no singular, como se não existissem outros partidos. E também, não raro, evangélicos foram perseguidos por vários governos, por causa de sua militância aprista. O Apra foi um partido cujas lideranças, em várias conjunturas, tiveram que permanecer na clandestinidade. Durante a primeira metade do século 20 evangélicos e apristas viveram a experiência comum de serem perseguidos, uns pela Igreja Católica, outros por governos de direita ou pelos militares. O próprio fundador do Partido Aprista, Victor Raul Haya de la Torre, durante períodos na clandestinidade e sob risco de morte, esteve protegido e escondido num colégio evangélico. Essa relação "normal" de simpatia e fraternidade entre evangélicos e apristas só mudaria na década de 80 , quando os filhos dos evangélicos entraram em contato com outras ideologias, outras visões de mundo, especialmente nas universidades públicas. Essa nova geração de evangélicos revelou-se mais simpática aos ideais da esquerda e passou a contestar a velha identificação dos evangélicos com o Partido Aprista. Como conseqüência, nas famílias e igrejas evangélicas gerou-se uma fobia com relação à universidade, que passou a ser vista como espaço de "perdição". Os pais consideravam que quem ingressava na universidade expunha-se a cair nas garras do "comunismo materialista".

Outro evangélico que incursionou na política foi Pedro Arana, que, em 1978, foi membro do Congresso Constituinte. Naquele ano o Peru estava retornando à democracia depois de 12 anos de ditadura militar. Pedro Arana era um importante líder da Igreja Presbiteriana (pastor laico) e engenheiro de formação. Na constituinte, foi membro também do Partido Aprista. A Igreja Presbiteriana no Peru, numericamente pequena, não tinha potencial de votos para eleger um candidato. Da mesma forma que ocorreu com Ferreira, a igreja de Arana não apoiava sua candidatura.

A entrada de jovens evangélicos nas universidades públicas nas décadas de 70 e 80 constituiu, sem dúvida, um importante fator de mudança na mentalidade evangélica a respeito da política. Alguns fatores devem ser frisados, 
embora nos limitemos a mencioná-los. A década do 70 corresponde ao auge dos movimentos populares, especialmente urbanos e ocorridos na capital Lima. Muitos filhos de protestantes migraram para a cidade visando ingressar nas universidades e procurar emprego. Essas décadas correspondem ao período de maior politização das universidades no Peru. Os atores políticos mais ativos nas universidades eram os sindicatos de professores e de trabalhadores e as organizações estudantis. É o período de maior fracionamento da esquerda, o que animou intenso debate político nas universidades. A respeito dos evangélicos há outros fatores que devem ser considerados. Os universitários evangélicos tinham sua própria organização, a Associação de Grupos Evangélicos Universitários do Peru (Ageup), cuja missão principal era evangelizar nas universidades. Seus fundadores viam com suspeita os partidos e as ideologias de esquerda. Mas a Ageup era uma associação que refletia sobre o lugar dos evangélicos na sociedade e na política. Finalmente, há que se considerar que em 1979 o Partido Comunista Sendero Luminoso deu início à luta armada, passando a agir na clandestinidade e a utilizar as universidades como espaço de propaganda ideológica.

$\mathrm{Na}$ década de 80 ocorreram diversas tentativas de organizar partidos evangélicos, mas todos tiveram vida efêmera. As iniciativas partiam de estudantes universitários que, sendo evangélicos e de setores populares, consideravam a esquerda um lugar impróprio para a militância política dos cristãos. Assim, surgiram, em 1980, o Frente Evangélico (FE) e, em 1985, a Associação Movimento de Ação Renovadora (Amar). Essa foi uma década de verdadeira comoção ideológica dos evangélicos. O Apra não era mais "o partido" dos evangélicos, uma nova geração procurava produzir um pensamento político religioso próprio. Outro fator de singular importância foi o impacto da literatura da Teologia da Libertação, que circulava com relativa freqüência entre as lideranças evangélicas mais jovens. Os livros do Padre Gustavo Gutiérrez, considerado fundador da Teologia da Libertação, passaram a ser lidos com atenção não apenas por jovens evangélicos, mas por pastores mais antigos, preocupados com as estranhas orientações políticas das novas gerações.

\section{Evangélicos na política}

As eleições gerais de 1990 constituem drástica mudança no comportamento político dos evangélicos. Os números de candidatos evangélicos e de 
evangélicos eleitos deram um enorme salto. Nunca antes os evangélicos tinham participado com tantos candidatos. Três elementos devem ser levados em consideração ao analisar essa mudança: o número e a procedência dos candidatos evangélicos, a participação das igrejas no processo eleitoral e as organizações políticas que usufruíram do voto dos evangélicos.

O processo eleitoral deste ano foi marcado pelo descrédito dos partidos políticos tradicionais. Nas eleições de 1979, que marcaram o retorno à democracia, triunfou o candidato dos dois partidos tradicionais de direita (Acción Popular e o Partido Popular Cristiano), Fernando Belaunde. Deposto pelos militares doze anos antes, Belaunde retornava ao poder. Nas eleições de 1985, pela primeira vez o velho Partido Aprista chegou ao poder, para a alegria das gerações mais velhas de evangélicos. $\mathrm{O}$ novo presidente era um jovem de 39 anos, Alan García, dotado de extraordinária capacidade retórica, recorrendo inclusive ao uso freqüente de metáforas bíblicas.

A decepção da população a respeito de ambos os governos, um de direita e outro de centro-esquerda, foi suficientemente grande para redirecionar seus votos, nas eleições de 1990, para o candidato independente. A conjuntura era apropriada para o sucesso de um "outsider". De fato, o vencedor do pleito foi Alberto Fujimori, candidato independente que organizou um "movimento independente" com o singelo nome de "Cambio 90". Fujimori venceu as eleições em segundo turno, momento em que houve inédita mobilização de capital simbólico religioso, tanto do lado dos evangélicos quanto do lado dos católicos. O candidato da direita era o conhecido escritor Mario Vargas Llosa (autor do romance A guerra do fim do mundo, inspirado nos acontecimentos de Canudos), que nunca antes havia sido candidato. Para a campanha do segundo turno, a Igreja Católica mobilizou suas forças em torno do argumento de que Fujimori representava os evangélicos e que uma possível vitória dos evangélicos colocava em perigo a catolicidade do país. Velhas rivalidades entre católicos e protestantes voltaram a ocupar importante espaço na imprensa e na opinião pública. Tradicionalmente, os protestantes levaram a pior, mas desta vez a mobilização católica homogeneizou os evangélicos em torno de um anticatolicismo.

O candidato evangélico de maior destaque fazia parte da chapa presidencial de Alberto Fujimori. Tratava-se do pastor batista Carlos Garcia, líder bastante conhecido e apreciado pelos evangélicos. Na lista de Fujimori can- 
didataram-se para o Senado 11 evangélicos, 4 dos quais foram eleitos. Para a Câmara de Deputados, havia 39 candidatos evangélicos, sendo 14 eleitos. Houve outros dois candidatos evangélicos nas filas do Apra. Ambos eram da Igreja Presbiteriana, e apenas um conseguiu ser eleito deputado. O outro era o pastor Pedro Arana, candidato a senador, que já estivera no Congresso Constituinte em 1978, mas que não foi eleito. Segue a distribuição dos candidatos eleitos para o Senado e a Câmara, por igreja e partido:

Quadro 1

Evangélicos eleitos em 1990 - Peru

\begin{tabular}{|l|c|c|c|}
\hline Igreja & $\begin{array}{c}\text { Número de } \\
\text { eleitos }\end{array}$ & Cargo & $\begin{array}{c}\text { Partido } \\
\text { Político }\end{array}$ \\
\hline Batista & 1 & Vice-Presidente & Cambio 90 \\
Cambio 90
\end{tabular}

Fonte: Onpe (Organismo Nacional de Procesos Electorales).

Ao todo foram eleitos 18 parlamentares evangélicos, sendo 15 de igrejas do protestantismo histórico e 3 de igrejas pentecostais. As igrejas evangélicas carismáticas não apresentaram candidatos. Os evangélicos eleitos pertenciam a apenas 2 partidos. Pelo Cambio 90 elegeram-se 14 deputados e 4 senadores; pelo Apra foi eleito apenas 1 deputado. Todos os candidatos eleitos eram leigos. Entre os candidatos também havia pastores, mas nenhum deles foi eleito. O único "especialista" eleito foi o pastor Carlos García (Igreja Batista), eleito Segundo Vice-presidente da República. Mas é importante considerar que a maioria dos candidatos evangélicos gozava de elevado prestígio em suas respectivas igrejas para mobilizar votos a seu favor. Por exemplo, o Senador Julián Bustamante era proprietário de uma indústria de fogões e de móveis de escritório, que privilegiava os funcionários evangélicos. Os candidatos a postos de trabalho na empresa de Bustamante tinham mais sucesso se 
eram evangélicos. Bustamante era leigo na sua igreja e nunca foi pastor, mas era conhecido e chamado pelos evangélicos de "Don Julián", e não como “irmão Julián”, que seria a forma comum entre os evangélicos. Bustamante preferia ter funcionários evangélicos, pois serem mais pontuais, dedicados e não participavam dos grêmios de trabalhadores.

Em comparação com a história prévia da participação de evangélicos na disputa eleitoral, as eleições de 1990 marcaram uma mudança radical, tanto em número de candidatos quanto em participação das igrejas dos candidatos. Embora as igrejas não assumissem ter um ou mais candidatos, facilitaram o trabalho de propaganda, cedendo espaço para reuniões etc. A mobilização da Igreja Católica teve como efeito exacerbar e reanimar uma certa identidade evangélica anticatólica. Ao mesmo tempo, os evangélicos se sentiam pela primeira vez perto do poder e com a real possibilidade de obter privilégios e vantagens que, até então, no decorrer de toda a história republicana haviam sido usufruídos apenas pela Igreja Católica. No calor da campanha eleitoral, Fujimori chegou a ser chamado de "irmão" e até de "escolhido por Deus".

O primeiro turno das eleições de 1990 teve como vencedor, embora sem maioria suficiente para eleger-se, o candidato da direita Mario Vargas Llosa. O discurso de campanha de Vargas não ocultava a intenção de ajustar-se a um drástico modelo econômico neoliberal. Em segundo lugar ficou Alberto Fujimori, cuja campanha estava centrada no slogan "honradez, tecnologia e trabalho". A campanha para o segundo turno mobilizou extraordinário capital simbólico religioso. As forças políticas de direita se articularam em torno da Igreja Católica, que viu no número de evangélicos candidatos sério risco para a manutenção de seus tradicionais privilégios. Imagens típicas do catolicismo peruano foram ativadas e mobilizadas pela imprensa e ganharam as ruas da capital. A direita tentou tirar proveito da força simbólica do catolicismo, mas não obteve sucesso. O povo, incluindo os evangélicos, tinha fortes razões para não votar no candidato de direita. Esse fator fundamental foi reinterpretado pelos evangélicos de modo triunfalista: Fujimori teria sido eleito graças ao voto dos evangélicos. A vitória de Fujimori deve ser entendida como resultado de um processo de dez anos em que os partidos de direita esgotaram a sua credibilidade, os partidos do centro (Apra) fracassaram no governo e a esquerda permaneceu sem espaço de ação política e sem credibilidade. Para entender esse último fator, há que se lembrar que desde o início do período democrático pós-ditadura militar (1979), a sociedade peruana experimentou 
inédita violência política-militar. Precisamente em 1979 uma das facções da esquerda radical, o Partido Comunista Sendero Luminoso, de orientação maoísta, decidiu abandonar o jogo democrático e partir para a clandestinidade. Em 1984, outro partido de esquerda tomou semelhante decisão: o Movimiento Revolucionario Tupac Amaru (Mrta), de orientação guevarista. Durante mais de duas décadas esses dois movimentos subversivos mantiveram em xeque os sucessivos governos de Fernando Belaunde (1980-1985), de Alan García (1986-1990) e os primeiros anos do governo de Alberto Fujimori. Por seu lado, a ação político-militar da polícia e do exército, no interesse de exterminar os "grupos terroristas", instauraram uma situação cotidiana de violação dos Direitos Humanos. Recente informe da Comissão da Verdade revela um saldo de vítimas próximo de 70 mil mortos.

Logo no início do mandato, Fujimori mudou repentinamente de discurso e adotou uma política econômica neoliberal. Em outros termos, Fujimori aplicou um plano econômico contra o qual o povo tinha votado nas eleições. Mas Fujimori não tinha obtido maioria no Congresso, nem sucesso nas alianças com os outros partidos. Assim, decidiu, em abril de 1992, com apoio pleno do exército, fechar o Congresso em ato que ficou conhecido como "auto-golpe de Estado", e iniciar um período especial, que nomeou de "Governo de emergência e reconstrução nacional”. Os meios de comunicação noticiaram que a medida autoritária contava com amplo apoio popular. Hoje há evidências de que, desde os primeiros anos de governo fujimorista, a mídia permaneceu controlada ou comprada diretamente pelo Sistema de Inteligência Nacional (SIN). A partir do "auto-golpe", a sociedade política e a sociedade civil passaram a expressar seu descontentamento. Importante grupo de evangélicos posicionou-se contrário ao sistema antidemocrático instaurado. Os protestos só não tiveram maior efeito por dois fatores: um foi o controle cada vez maior da imprensa e dos meios de comunicação (jornais, tv, rádio etc) por parte do Estado através do Serviço de Inteligência Nacional; outro foi a política populista de Fujimori de distribuição de bens entre os setores e regiões mais pobres do país. A pressão internacional obrigou Fujimori a convocar eleições para um novo Congresso Constituinte, denominado Congresso Constituinte Democrático (CCD). As eleições foram realizadas em novembro de 1992 (8 meses depois do "auto-golpe"). Nelas, os candidatos de Fujimori obtiveram mais do $50 \%$ das vagas (44 de 80 congressistas). Com esse controle do Congresso, Fujimori passou a governar com mais liberdade e 
sem oposição eficaz no parlamento. Apenas quatro evangélicos foram eleitos para o CCD, todos das fileiras do fujimorismo. Dois deles já eram deputados no período 1990-1992. Outros seis evangélicos candidataram-se por partidos de oposição, mas nenhum deles se elegeu. A maioria dos políticos evangélicos que ingressou no Congresso pelo partido de Fujimori foi obrigada a se posicionar a favor do ou contra o Governo. Os quatro evangélicos reeleitos apoiavam irrestritamente o governo.

Nas eleições de 1995, os evangélicos voltaram a participar e com um número grande de candidatos, tanto nas fileiras do partido governista quanto em partidos de oposição e independentes. No total havia 57 candidatos evangélicos, distribuídos em nove partidos ou movimentos políticos. Apenas cinco candidatos evangélicos foram eleitos, todos do partido governista. $\mathrm{O}$ quadro 2 mostra a distribuição dos candidatos por tendência evangélica. Classificamos os evangélicos em três grandes blocos: protestantes históricos, pentecostais e evangélicos carismáticos. Esta classificação procura distinguir o tipo de evangélico que irá ganhando espaço na prática política peruana.

\section{Quadro 2}

Candidatos evangélicos x igrejas - Peru eleições de 1995

\begin{tabular}{|c|c|c|c|}
\hline $\begin{array}{l}\text { Protestantismo } \\
\text { histórico }\end{array}$ & & Pentecostais & $\begin{array}{l}\text { Evangélicas } \\
\text { Carismáticas }\end{array}$ \\
\hline Bautistas & 22 & Asamblea de Dios & $\begin{array}{l}\text { Alianza Cristiana y } \\
\text { Misionera }\end{array}$ \\
\hline Presbiterianos & 7 & Iglesia Pentecostal & Misión de Cristo \\
\hline Iglesia Evangélica & & Pentecostal del Perú 1 & Movimiento Misionero \\
\hline Peruana & 4 & & Mundial \\
\hline Metodista & 2 & Pentecostal Misionera 1 & Camino de Vida \\
\hline Luterana & 2 & & Palabra de Fe \\
\hline Wesleyana & 1 & & \\
\hline Peregrinos & 1 & & \\
\hline Total & 39 & Total & Total \\
\hline Porcentagem & $69 \%$ & $19 \%$ & $12 \%$ \\
\hline
\end{tabular}

Fonte: Onpe (Organismo Nacional de Procesos Electorales). 
O quadro 3 mostra os partidos pelos quais os candidatos evangélicos participaram nas eleições de 1995.

Quadro 3

Candidatos evangélicos x partidos - Peru eleições 1995

\begin{tabular}{|l|c|c|}
\hline Partidos & $\begin{array}{c}\text { Candidatos } \\
\text { evangélicos }\end{array}$ & Eleitos x igreja \\
\hline Partido Reformista del Perú & 19 & 0 \\
\hline Unión por el Perú & 11 & 0 \\
\hline Movimiento Nuevo Perú & 9 & 0 \\
\hline Apertura para el Desarrollo & 7 & 0 \\
\hline Cambio 90 (Partido no poder) & 6 & $\begin{array}{c}\text { Protestant. histórico: } 4 \\
\text { Pentecostais: } 1\end{array}$ \\
\hline Frenatraca & 1 & 0 \\
\hline Code & 1 & 0 \\
\hline Movimiento Obras & 1 & 0 \\
\hline Partido Popular Cristiano & 1 & 5 \\
\hline Partido Aprista Peruano & 1 & 0 \\
\hline Total & 57 & \\
\hline
\end{tabular}

Fonte: Onpe (Organismo Nacional de Procesos Electorales).

É evidente que nessa campanha não houve políticas de alianças nem negociações no interior das igrejas evangélicas. Os candidatos evangélicos se apresentaram sem maior articulação. $\mathrm{O}$ grande número de candidatos evangélicos mostra também suas expectativas individuais em relação ao prestígio e à ascensão social particular. Exemplo eloqüente disso foi o Projeto de Lei apresentado pelo deputado evangélico Gilberto Siura, visando outorgar aos congressistas o direito a se aposentarem com um salário igual ao recebido durante o último ano de mandato. Alguns candidatos evangélicos receberam apenas três, dois votos. O partido governista apresentou apenas seis candidatos evangélicos, dos quais cinco foram eleitos. Hoje, a lisura do processo eleitoral em que Fujimori foi reeleito no primeiro turno é contestada.

Nas eleições de 2000, Fujimori apresentou-se novamente como candidato, contrariando a Constituição da República, que permitia apenas uma reeleição. Fujimori ganhou em segundo turno (maio), mas em processo compro- 
vadamente fraudulento e ilegítimo perante a opinião pública nacional e internacional. Devido ao descrédito geral e a mobilização da população nas ruas, o exército se apressou em realizar uma cerimônia de reconhecimento de Fujimori. Para isso, mobilizou suas forças em ações orientadas a intimidar a sociedade civil. Mas esta última passou a expressar abertamente seu rechaço ao governo. A crise conjuntural em torno do terceiro mandato de Fujimori encerrou-se em novembro de 2000, quando, depois de tornar-se público o mecanismo pelo qual Fujimori e o SIN compravam e mantinham submissos líderes políticos civis e militares, congressistas, donos de meios de comunicação, ministros, empresários, oficiais da polícia e do exército, o presidente renunciou, fugiu do país e se refugiou no Japão. A televisão exibiu um vídeo em que o principal assessor de Fujimori, Vladimiro Montesinos, entregava dinheiro a autoridades do Congresso, do Exército, da Polícia etc.

Nas eleições de 2000, os evangélicos tiveram importante participação, tanto no processo eleitoral quanto na opinião pública e na ação da sociedade civil, se posicionando a favor do ou contra o governo Fujimori. Foram 35 candidatos evangélicos no total, dos quais três das fileiras fujimoristas e 32 de outros oito partidos. Chama a atenção que alguns candidatos pentecostais e evangélicos carismáticos se apresentaram nas fileiras de um partido (Frepap) fundado pelo líder de uma igreja com características messiânicasmilenaristas (Quadro 5), a Israelita do Novo Pacto Universal, cujo fundador, Ezequiel Ataucusi, foi candidato a presidente. Unanimemente, os evangélicos não a consideram uma igreja evangélica.

Os números revelam também que os evangélicos perderam a confiança em Fujimori. Os candidatos evangélicos pertenciam a 17 igrejas, com predominância de denominações carismáticas (Quadro 4). Apenas um candidato evangélico foi eleito, na verdade reeleito, das fileiras do partido de Fujimori. 


\section{Quadro 4}

Candidatos evangélicos $\mathrm{x}$ igrejas - Peru eleições 2000

\begin{tabular}{|c|c|c|c|}
\hline \multicolumn{2}{|c|}{ Protestantes históricos } & \multirow{2}{*}{\begin{tabular}{|l} 
Pentecostais \\
Pentecostal del Peru 3
\end{tabular}} & $\begin{array}{l}\text { Evangélicos } \\
\text { carismáticos }\end{array}$ \\
\hline Bautista & 4 & & $\begin{array}{l}\text { Alianza Cristiana y } \\
\text { Misionera }\end{array}$ \\
\hline Presbiteriana & 4 & Asambleas de Dios 2 & Bíblica Emanuel \\
\hline $\begin{array}{l}\text { Iglesia Evang } \\
\text { Peruana }\end{array}$ & 3 & $\begin{array}{l}\text { Pentecostal } \\
\text { Misionera }\end{array}$ & Bíblica de Fé \\
\hline Wesleyana & 1 & Rosa del Sarón & Aposento Alto \\
\hline Metodista & 1 & Iglesia Pentecostal 1 & Misión de Cristo \\
\hline & & & Torre Fuerte \\
\hline & & & $\begin{array}{l}\text { Comunidad Cristiana } \\
\text { de Fe }\end{array}$ \\
\hline Total & 13 & Total & Total \\
\hline Porcentagem & $37 \%$ & $23 \%$ & $40 \%$ \\
\hline
\end{tabular}

Fonte: Onpe (Organismo Nacional de Procesos Electorales).

\section{Quadro 5}

Candidatos evangélicos x partidos - Peru eleições 2000

\begin{tabular}{|l|c|c|}
\hline Partido & Candidatos evangélicos & Eleitos x igreja \\
\hline Somos Perú & 10 & 0 \\
\hline Unión por el Perú & 6 & 0 \\
\hline Perú Posible & 5 & 0 \\
\hline $\begin{array}{l}\text { Alianza Perú } 2000 \\
\text { (Fujimorista) }\end{array}$ & 3 & 1 (Bautista) \\
\hline $\begin{array}{l}\text { Frente Independiente } \\
\text { Moralizador }\end{array}$ & 3 & 0 \\
\hline Frepap & 3 (2 pentecostais e 1 carismático) & 0 \\
\hline Avancemos & 2 & 0 \\
\hline Sode & 2 & 0 \\
\hline Para & 1 & 0 \\
\hline Total & 35 & 1 \\
\hline
\end{tabular}

Fonte: Onpe (Organismo Nacional de Procesos Electorales). 
Os dados mostram que mais uma vez os evangélicos careceram de articulação para concentrar os votos dos fieis. A diversidade institucional evangélica reproduziu-se na dispersão de votos. Uma característica comum na propaganda eleitoral dos candidatos evangélicos procurava explorar os seguintes dois elementos: honradez, que supostamente faz parte da ética evangélica desde as suas origens e, em segundo lugar, a autenticidade religiosa: "compromisso com Deus", "em defesa dos valores cristãos" e assim por diante.

Setores da sociedade civil se posicionaram contra as pretensões eleitorais de Fujimori e os evangélicos, mais ou menos articulados, se mobilizaram junto com organizações sociais desfilando pelas ruas ou emitindo pronunciamentos na mídia, expressando seu rechaço às intenções do presidente de se manter no poder por até 15 anos ou mais. Destacamos uma carta pública do Concilio Nacional Evangélico del Peru (Conep), emitida em janeiro de 2000, a escassos três meses das eleições. A carta tinha o eloqüente título "Por qué los cristianos debemos rechazar la segunda reelección del señor Fujimori?".

Com a saída repentina de Fujimori e a renuncia dos dois vicepresidentes, assumiu o poder, conforme a Constituição, o presidente do Congresso, Valentin Paniagua, cuja função fundamental consistiu em convocar novas eleições para 2001. Nessas eleições os evangélicos participaram com 30 candidatos, dos quais apenas três foram eleitos. Dois deles da Igreja Batista e um do Ministério Verbo, de perfil carismático. Os três eleitos tinham em comum o fato de serem representantes de regiões do interior do país (Amazonas, Ucayali e Ayacucho) bastante pobres e, regra geral, esquecidas por sucessivos governos. Outros candidatos evangélicos obtiveram votação bem mais elevada na capital, mas não foram eleitos porque a concorrência em Lima é maior. Os evangélicos não tiveram força para concorrer nem na capital nem nas maiores cidades. É importante destacar que as regiões de Ucayali, Amazonas e Ayacucho seriam, segundo pesquisa realizada por instituições evangélicas em 2003, as de maior densidade de evangélicos: 25,7\% no Amazonas, 26\% em Ucayali, 21,1\% em Ayacucho; maior ainda que os 12,8\% de Lima (Manual Estadístico, 2003, p. 46).

Somados os votos de todos os candidatos evangélicos, chega-se ao total de 190.794 votos. Quantidade bem menor do que o número de evangélicos no país, segundo a própria estimativa desses religiosos, que na época consideravam ter cerca de dois milhões de fiéis. O censo de 1993 revela que os evan- 
gélicos eram $6,7 \%$ da população (1.042.888), considerando a população maior de 12 anos. Em 1993, os evangélicos tinham 870.242 adeptos com 18 ou mais anos, aptos a votar. Em 2001 esse número seria maior. Mas nessas eleições o total de votos recebidos pelos candidatos evangélicos foi de apenas 190.794. A conclusão é que os evangélicos não conseguiram, nem de longe, mobilizar grande parte do voto dos próprios irmãos em favor dos candidatos evangélicos (Quadro 6). O mesmo se pode dizer das eleições de 1995 e de 2000. No primeiro caso, os candidatos evangélicos conseguiram 98.236 votos e, em 2000, 147.098 votos.

\section{Quadro 6}

\begin{tabular}{|c|c|c|c|c|}
\hline \multicolumn{5}{|c|}{ População $>$ ou $=12$ anos $x$ religião $(1993)$ e votos evangélicos 2001} \\
\hline Religião & $\begin{array}{l}>\text { ou }=12 \\
\text { anos }\end{array}$ & $\begin{array}{l}>\text { ou }=12 \\
\text { anos } \\
\%\end{array}$ & $\begin{array}{l}>\text { ou }=18 \\
\text { anos }\end{array}$ & $\begin{array}{l}\text { Votos obtidos } \\
\text { por candidatos } \\
\text { evangélicos em } \\
2001\end{array}$ \\
\hline Católicos & 13.786 .000 & $89 \%$ & 12.988 .696 & \\
\hline Evangélicos & 1.042 .888 & $6,7 \%$ & 870.242 & $190.794(22 \%)$ \\
\hline $\begin{array}{l}\text { Outra } \\
\text { Religião }\end{array}$ & 397.825 & $2,5 \%$ & & \\
\hline $\begin{array}{l}\text { Sem } \\
\text { Religião }\end{array}$ & 222.141 & $1,4 \%$ & & \\
\hline \multirow[t]{2}{*}{$\begin{array}{l}\text { Não } \\
\text { responde }\end{array}$} & 34.935 & $0,4 \%$ & & \\
\hline & 15.483 .789 & $100 \%$ & & \\
\hline
\end{tabular}

Fonte: Inei (Instituto Nacional de Estadística e Informática).

A partir das eleições de 1990 os evangélicos não deixaram de participar, mas, com exceção dessas eleições, os candidatos evangélicos se apresentaram sempre em variados e diversos partidos. $\mathrm{Na}$ grande maioria dos casos os partidos eram sempre independentes. Os evangélicos aprenderam que havia menor chance de obter lugar na lista dos partidos tradicionais. Ou os partidos tradicionais não abriram espaço nem se interessaram pelo voto evangélico. A participação política dos evangélicos está mudando de maneira clara e a tendência é de maior participação dos carismáticos, em detrimento de pentecostais e históricos. Nas eleições de 2001, 50\% dos candidatos evangélicos eram 
de igrejas carismáticas (Quadro 7). O dado assume maior relevância quando se observa que em 1990 esse segmento evangélico não teve candidato a Presidente.

\section{Quadro 7}

Candidatos evangélicos $\mathrm{x}$ igrejas - eleições 2001

\begin{tabular}{|c|c|c|c|}
\hline $\begin{array}{l}\text { Protestantes } \\
\text { históricos }\end{array}$ & & Pentecostais & $\begin{array}{l}\text { Evangélicos } \\
\text { carismáticos }\end{array}$ \\
\hline Bautista & 6 & $\begin{array}{l}\text { Pentecostal } \\
\text { de Jesucristo } 1\end{array}$ & $\begin{array}{l}\text { Alianza Cristiana } \\
\text { y Misionera }\end{array}$ \\
\hline $\begin{array}{l}\text { Iglesia Evangélica } \\
\text { Peruana }\end{array}$ & 2 & $\begin{array}{l}\text { Pentecostal } \\
\text { Misionera }\end{array}$ & Bíblica Emanuel \\
\hline Nazarena & 2 & $\begin{array}{l}\text { Evangélica } \\
\text { Pentecostal }\end{array}$ & Interdenominacional \\
\hline Wesleyana & 1 & & Apocento Alto \\
\hline \multirow[t]{6}{*}{ Presbiteriana } & 1 & & Ministério Verbo \\
\hline & & & Avivamiento Emanuel 1 \\
\hline & & & $\begin{array}{l}\text { Movimiento Misionero } \\
\text { Mundial }\end{array}$ \\
\hline & & & De Cristo Misionera \\
\hline & & & Cristiana Shalom \\
\hline & & & Camino de Vida \\
\hline Total & 12 & Total & Total \\
\hline Porcentagem & $40 \%$ & $10 \%$ & $50 \%$ \\
\hline
\end{tabular}

Fonte: Onpe (Organismo Nacional de Procesos Electorales).

O Quadro 8 confirma que os evangélicos no Peru continuaram pouco articulados. Os 30 candidatos estavam distribuídos em 10 partidos diferentes. 


\section{Quadro 8}

Candidatos evangélicos x partido - eleições de 2001

\begin{tabular}{|l|c|c|}
\hline Partido & $\begin{array}{l}\text { Candidatos } \\
\text { evangélicos }\end{array}$ & Eleitos x igreja \\
\hline $\begin{array}{l}\text { Cambio 90/Nueva } \\
\text { Mayoría } \\
\text { (fujimorista) }\end{array}$ & 7 & 0 \\
\hline Proyecto país & 5 & 0 \\
\hline Apra & 4 & 2 (Iglesia Bautista) \\
\hline Perú Posible & 3 & 0 \\
\hline Todos por la victoria & 3 & 0 \\
\hline Somos Perú & 3 & 0 \\
\hline FIM & 2 & 0 \\
\hline Unión por el Perú & 1 & 0 \\
\hline Renacimiento Andino & 1 & 0 \\
\hline Unidad Nacional & 1 & 3 \\
\hline Total & 30 & (Evang. carismático) \\
\hline
\end{tabular}

Fonte: Onpe (Organismo Nacional de Procesos Electorales).

Cabe destacar também a importante presença de candidatos mulheres nas eleições de 2001 (Quadro 9). A porcentagem de mulheres no total de candidatos (evangélicos e não evangélicos) foi de $35 \%$. A porcentagem de candidatos evangélicos mulheres aumentou a cada eleição nos pleitos de 1995, 2000 e 2001. Sendo neste último ano de 30\%. Esse dado surpreende porque as igrejas evangélicas no Peru, salvo exceções, não permitem a ordenação de mulheres para exercer cargos de liderança nas congregações.

\section{Quadro 9}

Mulheres entre os candidatos evangélicos nas últimas eleições

\begin{tabular}{|c|c|c|}
\hline 1995 & 2000 & 2001 \\
\hline $12 \%$ & $25 \%$ & $30 \%$ \\
\hline
\end{tabular}

Fonte: Onpe (Organismo Nacional de Procesos Electorales). 


\section{Quadro 10}

\section{Candidatos evangélicos $x$ tradição religiosa até as eleições de 2001}

\begin{tabular}{|l|c|c|c|c|c|}
\hline Ano & $\begin{array}{c}\text { Candida- } \\
\text { tos } \\
\text { Evangéli- } \\
\text { cos }\end{array}$ & $\begin{array}{c}\text { Protestantis- } \\
\text { mo } \\
\text { Histórico }\end{array}$ & Pentecostais & $\begin{array}{c}\text { Evangélicos } \\
\text { Carismáticos }\end{array}$ & Total \\
\hline 1990 & 19 & $83 \%$ & $17 \%$ & $0 \%$ & $100 \%$ \\
\hline 1995 & 57 & $69 \%$ & $19 \%$ & $12 \%$ & $100 \%$ \\
\hline 2000 & 35 & $37 \%$ & $23 \%$ & $40 \%$ & $100 \%$ \\
\hline 2001 & 30 & $40 \%$ & $10 \%$ & $50 \%$ & $100 \%$ \\
\hline
\end{tabular}

Fonte: Onpe (Organismo Nacional de Procesos Electorales).

Quando se compara a participação dos evangélicos nas últimas eleições (Quadro 10), observa-se expressivo aumento da participação de candidatos de igrejas carismáticas. Em 1990 essas igrejas não apresentaram candidatos. Apenas uma década depois, a maioria dos candidatos provém delas. De fato, foram essas igrejas que difundiram um novo discurso teológico justificando a participação política. Analisaremos essa questão no caso do partido evangélico "Restauração Nacional”, considerando-se dados das últimas eleições de 2006.

\section{O "candidato de Deus" nas eleições de 2006}

Nas eleições de 2001 não existia a figura do "candidato evangélico" à presidência. Enorme dispersão de candidatos, pouquíssima articulação, precária organização e quase nenhuma experiência de propaganda eleitoral contrastavam com o grande número de candidatos. Nenhum dos candidatos evangélicos tinha base política própria e as igrejas apenas timidamente expressavam sua preferência eleitoral. O cenário eleitoral contemporâneo (2006) mostra claras diferenças com a situação anterior. Nas eleições de 2006, havia dois partidos evangélicos organizados e com candidatos à presidência do país: Reconstrução Democrática e Restauração Nacional. Ambos podem ser chamados de partidos evangélicos por duas razões: foram fundados por evangélicos e incluem como parte de seus fundamentos políticos a fé evangélica. Em comum, ambos são dirigidos por setores evangélicos carismáticos. A seguir observamos as características mais importantes do Partido Restauração Nacional. Sua escolha deve-se ao impacto que teve nos resultados eleitorais deste ano. O outro 
partido evangélico apresentou em sua lista de candidatos à vice-presidência o pastor Marco Alcalde, das Assembléias de Deus, e Juana Avellaneda, membro da Igreja Yo Soy, de orientação carismática.

O partido Restauração Nacional foi fundado em 2000 pelo pastor carismático Humberto Lay, pastor da Iglesia Bíblica Emanuel. No final da década de 80, Lay fundou a denominação a partir de uma dissidência da igreja Alianza Cristiana y Misionera, de origem semelhante à do Evangelho Quadrangular no Brasil. A divisão ocorreu fundamentalmente em razão da renovação litúrgica que Lay tentara impor na Alianza Cristiana y Misionera. Seguindo a reflexão de teólogos pentecostais norte-americanos, Lay afirmou em 1999 que, no século 20, produziram-se três grandes mudanças na igreja cristã. A primeira era o derramamento do Espírito Santo no início do século, que originou o pentecostalismo e a Alianza Cristiana y Misionera. Segundo, o surgimento de um novo carismatismo na metade do século 20 na Igreja Católica e em igrejas fundamentalistas; terceiro, outro derramamento do Espírito Santo que, na metade dos anos 80 , gerou o movimento de louvor e adoração, quebrando os modelos litúrgicos tradicionais, frios e sem vida. Cabe mencionar que esse movimento tem crescido em diversos países da América Latina. $\mathrm{Na}$ maioria dos casos, seus líderes são fundadores e militantes de partidos políticos evangélicos. Para citar apenas um exemplo, o Movimiento Unión Cristiana na Colômbia, cujos fundadores são líderes da Igreja Cristã Centro de Louvor Oásis. No Peru, Lay é dirigente ainda da Fraternidad Interdenominacional de Pastores Cristianos (Fipac), que reúne líderes de diversas igrejas que enfatizam a renovação litúrgica no louvor e na adoração. Com sua mensagem, os dirigentes desse movimento visam atingir setores das classes meia e alta, além das classes populares. A igreja de Lay, em Lima, por exemplo, está localizada em San Isidro, um dos bairros nobres da cidade.

Em novembro de 2004 Lay afirmava que o partido não tinha intenções imediatas de propor candidato à Presidência do país, e sim apenas ao Congresso e a prefeituras. No início de abril de 2005, porém, o Partido Restauração Nacional anunciou a candidatura presidencial do pastor Humberto Lay. Em declarações à imprensa, Lay justificou o lançamento de sua candidatura, destacando a necessidade de um governo para restaurar os valores espirituais, o que só poderia ser realizado por meio de um partido político de "inspiração evangélica". Lay é arquiteto de formação e descendente de chineses. Em 2003, foi membro da Comissão da Verdade. Em agosto daquele ano, decla- 
rou: "o trabalho da comissão da verdade mudou minha vida". Ao longo do período de violência política, porém, Lay e sua igreja permaneceram indiferentes a essa realidade.

As eleições estavam programadas para o dia 9 de abril de 2006. Em janeiro, Lay tinha apenas $1 \%$ das intenções de voto. Era a primeira vez que um partido apresentava um candidato evangélico à Presidência. Era de se esperar, como realmente aconteceu, que o candidato evangélico fosse apresentado como "o candidato de Deus". Especialmente através da internet circularam inúmeras "profecias" a respeito da indicação divina para que os evangélicos votassem em Lay. A intensa propaganda teve algum efeito. Lay conseguiu pouco mais de $4 \%$ dos votos e ficou em sexto lugar de uma lista de 18 candidatos a Presidente. Quanto aos candidatos ao Congresso, nessas eleições houve recorde de candidatos evangélicos: 104 candidatos se apresentaram por oito diferentes partidos, além dos dois partidos evangélicos. Para a maioria desses candidatos, era a primeira aventura eleitoral. Foram 20 partidos concorrendo com candidatos ao Congresso, dos quais 10 apresentaram evangélicos. O partido de Humberto Lay conseguiu eleger dois membros ao Congresso, sendo uma mulher. Outra evangélica foi eleita (Maria Zumire) pelo partido Union por el Peru. Em relação às eleições anteriores a novidade está em candidatos evangélicos eleitos por voto secular, e não apenas pelo voto dos "irmãos"; fato que se explica pela militância dessas pessoas em organizações populares camponesas. É o caso de Maria Zumiri, da Igreja Metodista, eleita em representação da cidade do Cuzco. Zumire não poderia ter sido eleita apenas com os votos evangélicos. Menos ainda com os votos de sua própria denominação.

\section{Considerações finais}

A partir de 1990 observam-se mudanças na prática política dos evangélicos no Peru. Mudanças que refletem, ao mesmo tempo, que as igrejas evangélicas desenvolveram novas maneiras de entender seu compromisso social. Antes de 1990 a participação política eleitoral dos evangélicos era bem modesta e limitava-se ao agir de poucos indivíduos "notáveis". Daí em diante uma das justificativas empregadas para justificar a participação política é que a igreja no mundo inteiro está passando por novo "despertar espiritual", sendo um de seus efeitos a "revisão de seu papel no mundo". O grande número de candidatos nas eleições de 1990 marca assim um divisor de águas na rela- 
ção entre evangélicos e política eleitoral. Nos cinco processos eleitorais ocorridos posteriormente os evangélicos sempre apresentaram candidatos ao Congresso, e nas eleições de 2006 apresentaram também um candidato à presidência.

Os candidatos representavam as mais diversas tradições evangélicas. Para este trabalho elaboramos a seguinte classificação: protestantes históricos, pentecostais e evangélicos carismáticos. As igrejas "neopentecostais", tal como conhecidas no Brasil, ainda não conseguiram penetrar na sociedade peruana. Provavelmente um dos fatores seja a pouca possibilidade de explorar a televisão na transmissão de programas religiosos. Melhor sucesso têm conseguido igrejas de matriz pentecostal procedentes de Estados Unidos e América Central, que inovaram a sua liturgia em direção à ênfase no louvor. Essas igrejas, que aqui chamamos de evangélicas carismáticas, surgiram com marcada característica apolítica, mas são hoje as mais ativas em política eleitoral, deixando para trás pentecostais e protestantes históricos. O único candidato evangélico a Presidente, Humberto Lay, era precisamente de uma igreja evangélica carismática. Tudo indica que os evangélicos continuarão nessa prática política. Segundo a imprensa anuncia nas últimas semanas, Lay se prepara agora para lançar sua candidatura à prefeitura da cidade de Lima, capital do país.

\section{Referências}

ADRIANZÁN, Alberto (Org.). Pensamento político peruano 1930-1968. Lima: Desco, 1990.

CONTRERAS, Carlos; CUETO. Marcos. Historia del Peru contemporâneo. Lima: IEP, 2004.

FONSECA, Juan, Misioneros y civilizadores: protestantismo y modernización en el Peru (19151930). Lima: Pucp, 2002.

LOPEZ, Dario, La seducción del poder. Lima: Nueva Humanidad, 2004.

PADILLA, René (Org.). De la marginación al compromiso: los evangélicos y la política en América Latina. Quito: FTL, 2001.

Peru para Cristo, Manual Estadístico 2003: investigación sócio-religiosa. Iglesia Evangélica, Lima: Nuevo Rumbo, 2004.

SMITH, Brian. Religious politics in Latin America. Pentecostal vs Catholic. Indiana: Notre Dame, 1984.

Recebido em 2 de setembro de 2006 e aprovado em 18 de setembro de 2006 